\title{
An Empirical Research on the Relationship Between Financial Service Trade and Financial Industry of Shanghai
}

\author{
Yan Xu*, Lili Yu \\ School of Economics, Shanghai University, Shanghai, China \\ Email address: \\ smily1027@126.com (Yan Xu),yuli537@163.com (Lili Yu)
}

To cite this article:

Yan Xu, Lili Yu. An Empirical Research on the Relationship Between Financial Service Trade and Financial Industry of Shanghai. International Journal of Economics, Finance and Management Sciences. Vol. 3, No. 5, 2015, pp. 646-649. doi: 10.11648/j.ijefm.20150305.41

\begin{abstract}
Based on VAR model, the paper studies the relationship between financial service trade and financial industry of Shanghai through Co-integration theory. The results confirm that the equilibrium relationship between financial service trade and financial industry of Shanghai actually exists in the long term, and the relationship between import in financial service trade and financial industry is more significant. Under the condition of two phases lag, financial industry is the one-way Granger cause of financial service trade of Shanghai. Besides, the mechanism of interactive development is also been analyzed.
\end{abstract}

Keywords: VAR Model, Co-integration Theory, Interactive Development

\section{Introduction}

Along with the development of financial reform, China's financial service trade has stepped in the golden period of development. Preparation of Maritime Silk Road and output of Infrastructure Capacity will bring an increase in the export of insurance and other financial service. Besides, it will also create a new growth point for China's financial development.

As the financial center of China, Shanghai is also the core city of economic circle of the Yangtze River Delta, and the development of its financial sector has always been at the forefront across the country, but the amount of financial trade is obviously not a match with the financial status of Shanghai. In 2013, added value of financial industry of Shanghai was 282.3 billion RMB, but the trade volume was only 5.57 billion dollars. That's 33.96 billion yuan in the conversion to the spot exchange rate at the end of 2013. It's shown that there's a huge gap between Shanghai's financial service trade and financial industry, and the interaction between the trade and finance seems not to be significant, which is bad for the city to seize the opportunity to realize double-linkage development of financial service trade and financial industry.

Therefore, exploring the interaction between financial service trade and financial industry has important practical significance.

Researches related are mainly focused on two directions: one is the study of the interaction between trade in service and service industry, S. L. Wang, Z. B. Hu and Y. Z. Wang, J. $Z$. Wang respectively use the VAR model and VECM model to carry out empirical analysis on the interaction between trade in service and service industry of China. They both come to conclusions that there's a stable equilibrium relationship between trade in service and service industry in the long term. But they have a disagreement in the Granger test results $[1,2]$. C. H. Pei and Z. Y. Yang find that science and technology innovation, FDI as well as institutional change are the main reason for the fast growth in service industry [3]. The other direction is to study the promotion of trade in service to economic growth, a lot of researches indicate that there's a stable equilibrium relationship between trade in service and economic growth [4-9].

\section{Methodology}

Vector Autoregression Model (VAR) is proposed by Christopher Sims, using some lagged variables from all current variables of the model to conduct regression analysis, and promoting the univariate autoregression model to level of the "vector" autoregressive model composed by multivariate time series variables. VAR model is easy to test the existence of stable relationship between each variable of the model for a long term, without the necessity of making preliminary assumption of the endogeneity and exogeneity for variables in the model. It's an ideal model for cointegration analysis. Therefore, this article conducts empirical analysis on the interaction between Shanghai financial service trade and 
financial sector by selection of VAR model.

Mathematical expression of VAR model goes as follows:

$$
\mathrm{Y}_{\mathrm{t}}=\mathrm{A}_{1} \mathrm{Y}_{\mathrm{t}-1}+\mathrm{A}_{2} \mathrm{Y}_{\mathrm{t}-2}+\cdots+\mathrm{A}_{\mathrm{p}} \mathrm{Y}_{\mathrm{t}-\mathrm{p}}+\mathrm{BX}_{\mathrm{t}}+\varepsilon_{\mathrm{t}}(\mathrm{t}=1,2 \ldots, \mathrm{T})
$$

The characters are explained as follows: $Y_{t}$ are k-dimension endogenous variables; $X_{t}$ are d-dimension exogenous variables; $\mathrm{p}$ is the lag order; $\mathrm{T}$ stands for sample number; $\varepsilon_{\mathrm{t}}$ is the $\mathrm{k}$-dimension random disturbance, which can be contemporaneous correlation with each other with no correlation with the lagged value. The covariance matrix of $\varepsilon_{\mathrm{t}}$ is a positive definite matrix.

The studying model is built in this paper:

$$
\mathrm{Y}_{\mathrm{t}}=(\mathrm{FIN}, \mathrm{EX}, \mathrm{IM})^{\prime}
$$

FIN indicates the level of development of financial services industry, EX indicates the exports of financial service trade, IM indicates the imports of financial services trade. FIN, EX, IM are all endogenous variables.

There're "Insurance" item and "Other Finance" item in the trade of service. The paper adds the two items up as "Financial Trade" for the reason that the added value of financial sector statistics includes insurance. The Sample data is annual, and the sample period is 2000-2013. The data is from Shanghai Statistical Yearbook and Shanghai Service Trade Development Report in 2012. The article adopts standardized method to nondimensionalize the data.

\section{Empirical Analysis}

\subsection{ADF Test}

According to the theory of Econometrics, all variables must be stationary before regression, or there will be a "fake" or "nonsense" regression. In 1987, Engle and Granger put forward the theory and method of Cointegration. According to that, even some economic variables are non-stationary series, but their linear combinations are likely to be stationary series. The stationary linear combination is known as cointegration equation, and it's interpreted that the long-term stable equilibrium relationship exists between variables. Only variables with the same integration order may have cointegration. Therefore, this paper takes unit root test to all of the variables using ADF method.

Table 1. ADF Test Results.

\begin{tabular}{llll}
\hline Variable & Test Value & Critical Value & Conclusion \\
\hline FIN & -2.222039 & -3.828975 & Unstable \\
EX & -1.137445 & -3.175352 & Unstable \\
IM & -1.316261 & -1.974028 & Unstable \\
$\mathrm{D}(\mathrm{FIN}, 1)$ & -1.404924 & -3.175352 & Unstable \\
$\mathrm{D}(\mathrm{EX}, 1)$ & -3.429202 & -4.008157 & Unstable \\
$\mathrm{D}(\mathrm{IM}, 1)$ & -1.481126 & -1.974028 & Unstable \\
$\mathrm{D}(\mathrm{FIN}, 2)$ & -7.790513 & -3.175352 & Stable \\
$\mathrm{D}(\mathrm{EX}, 2)$ & -4.994049 & -1.988198 & Stable \\
$\mathrm{D}(\mathrm{IM}, 2)$ & -3.298422 & -1.977738 & Stable \\
\hline
\end{tabular}

According to test results in the table 1, the original sequence can't reject the unit root hypothesis under the 5\% significant level, which is the same with variables in the first order difference. However, all the variables reject the unit root hypothesis in the second order difference under $1 \%$ significant level. That is to say, all of the variable series are second-order integration.

\subsection{Johansen Test}

All variables series are for the second order list, so the cointegration analysis can be conducted with a model. This paper adopts Johansen Cointegration Test to judge whether there is a cointegration relationship between variable series. The optimal lag is 2 according to rule of AIC and SC principle, and there's only intercept of cointegration equation without trend term.

Table 2. Johansen Test Results.

\begin{tabular}{lllll}
\hline Eigenvalue & $\begin{array}{l}\text { Trace } \\
\text { Test } \\
\text { Statistics }\end{array}$ & $\begin{array}{l}\text { Critical } \\
\text { Value (5\%) }\end{array}$ & P Value & $\begin{array}{l}\text { Number of } \\
\text { Cointegration } \\
\text { Equation }\end{array}$ \\
\hline 0.981604 & 55.06162 & 29.79707 & 0.0000 & None * \\
0.571974 & 11.10970 & 15.49471 & 0.2049 & At most 1 \\
0.149049 & 1.775402 & 3.841466 & 0.1827 & At most 2 \\
\hline
\end{tabular}

Test results show that, there's a unique cointegration equation of Shanghai's financial service trade and financial industry at the $5 \%$ confidence level. The standardized co-integration equation is given through the Eviews6.0 software:

$$
\mathrm{FIN}=0.349401 \mathrm{EX}+1.253872 \mathrm{IM}
$$

$$
\text { s.e. }(0.02893) \text { (0.03823) }
$$

Likelihood Ratio $=19.46237$

According to the above equation, there's a long-term stable equilibrium relationship between financial service trade and financial industry of Shanghai. In the long run, with the other factors unchanged, when financial trade exports increase by $1 \%$, the financial sector increase by $0.349 \%$. In contrast, with other factors remain unchanged, when financial trade imports increase by $1 \%$, the financial sector increase by $1.254 \%$, which indicates that the interactive relationship between import in financial trade and financial industry is more significant.

\subsection{Granger Causality Test}

Cointegration test results show that there is a long-term stable equilibrium relationship between financial service trade and financial industry of Shanghai. But further examination is needed to test whether causal relationship exists in the equilibrium. This paper conducts the analysis with Granger Causality Test. Under the significance level of $5 \%$, the results are as listed below in table 3 . 
Table 3. Granger Causality Test Results.

\begin{tabular}{llll}
\hline Hypothesis & F & P & \multirow{2}{*}{ Conclusion } \\
& Statistics & Value & \\
\hline EX is not the Granger Cause of FIN & 1.27481 & 0.3372 & Accepted \\
FIN is not the Granger Cause of EX & 4.82511 & 0.0482 & Rejected \\
IM is not the Granger Cause of FIN & 0.27955 & 0.7642 & Accepted \\
FIN is not the Granger Cause of IM & 5.94038 & 0.0310 & Rejected \\
IM is not the Granger Cause of EX & 2.30136 & 0.1706 & Accepted \\
EX is not the Granger Cause of IM & 6.87919 & 0.0223 & Rejected \\
\hline
\end{tabular}

The table above shows that FIN is the Granger cause of EX and IM, but neither EX nor IM is the Granger cause of FIN. Besides, EX is the Granger cause of IM. That's to say, the development of financial industry will promote the development of the financial service trade to a certain extent, however, the adverse effect of financial service trade on financial sector is not significant, and for a period of time, financial trade exports can promote financial trade imports.

\subsection{Analysis of Empirical Findings}

There're a few findings in the empirical analysis. Firstly, the interaction between financial service trade and financial industry of Shanghai actually exists. Secondly, the interactive relationship between financial trade import and financial industry is more significant. Thirdly, the development of financial sector is the one-way Granger cause of financial service trade. The findings are consistent with the theoretical study and reality [10-15].

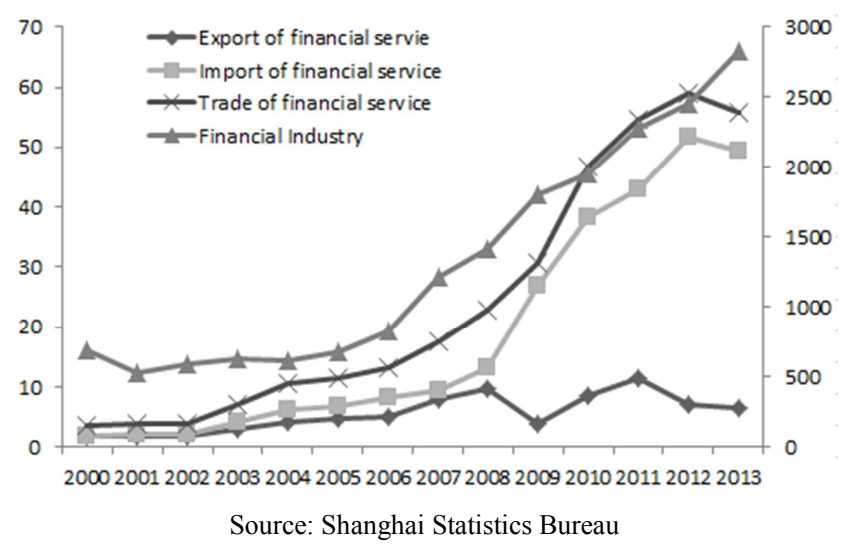

Figure 1. Financial trade and industry in Shanghai.

Then, what's the reason behind the appearance? Why financial industry is the one-way Granger cause of financial trade but the latter isn't the Granger cause of the former one? And why the interactive relationship between financial trade import and financial industry is more significant? The paper also digs out the reason of these questions.

Financial industry is the Granger cause of financial service trade, which is consistent with the traditional trade theory about Trade in Service. According to the theory, service industry is the basis of trade in service, and the development of trade in service is subject to service industry growth, and there's a strong correlation between them. The empirical studies of Shanghai indicate that the development of financial industry can promote the development of financial service trade indeed, and the driving effects have time-delay. But why financial service trade is not the Granger cause of the financial industry development, what are the reasons?

Studies show that trade in service affect services mainly through three channels: technology spillovers; human capital accumulation and institutional innovation. On the one hand, financial service trade has improved the financial risk control level and management ability of local financial institutions through the technology spillover effect. On the other hand, studying abroad has also promoted the comprehensive quality and professional ability of financial practitioners and through the human capital accumulation effect. Statistics released by the ministry of education service center in China show that business is preferred when Chinese students choose their major. But why financial service trade isn't the cause of financial industry? Because with the current financial and monetary policies, there are a lot of obstructions for the promoting effect to work, which results in the consequence that financial service trade hasn't a particularly significant influence on financial industry. For example, State-owned financial institutions have traditional management system in China at present stage, and personnel change is related to many factors, which leads to the difficulty for carrying out advanced financial management concept, while the financial institutions in China play an important role in the financial system of the country. From the other prospect, due to factors such as enterprise culture, welfare benefits, many abroad people tend to choose working in foreign company, which has hindered the human capital accumulation effect on promoting the development of the financial sector. Finally, it's still a short time since the capital market is set up, so the Supervisory Authorities don't still in lack of risk management experience in some areas, there's a lot of troubles in financial system revolution, so the impact which financial service trade has on financial system is not obvious.

Why the interactive relationship between financial trade import and financial industry is more significant? Back to the components of financial service trade, about $90 \%$ is insurance.

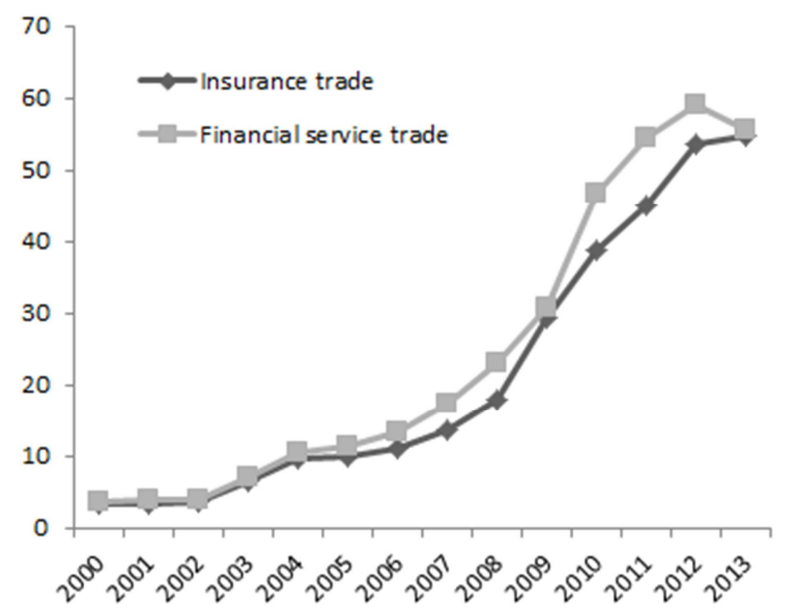

Source: Shanghai Statistics Bureau

Figure 2. Financial trade in Shanghai. 
The structure imbalance of insurance service trade is the reason why the interaction between import of financial service trade and financial industry is more significant. In 2013 , Import of insurance service trade reached $\$ 4.86$ billion, but exports is only $\$ 620$ million. Along with the rapid development of Shanghai financial industry, the import of insurance trade grows fast, but the volume of export is still less than $\$ 1$ billion.

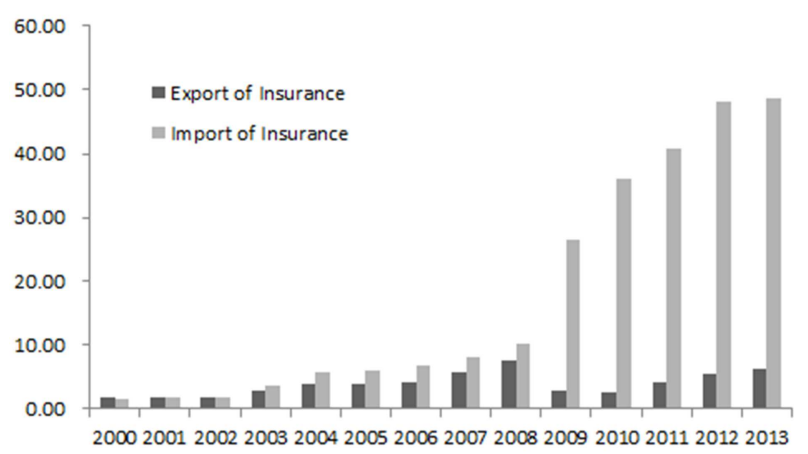

Source: Shanghai Statistics Bureau

Figure 3. Trade of Insurance in Shanghai.

Then why is there such a huge gap between export and import of insurance trade? There are two reasons for the rapid growth in import of insurance. One is the increase of trade in goods, and the other one is that foreign companies tend to choose overseas insurance institution or to use foreign currency to pay insurance cost. They do so in the thought of financial system and the need of the partner. By contrast, the export is subject to the economic environment and the degree of opening to the outside world in the insurance industry. Under the current financial system and capital policy, foreign investment in China's capital market has certain obstacles and barriers, export trade has been restricted. In 2008, the outbreak of the global financial crisis led to the sharp down of export of insurance service trade in 2009, and in 2010, the establishment of free trade zone between ASEAN and our China led to the increase of export in financial service.

\section{Conclusion}

This paper has conducted an empirical study in the relationship between financial service trade and financial industry of Shanghai using VAR model. It's found that the interaction between financial service trade and financial industry of Shanghai do exist, and the interactive relationship between financial trade import and financial industry is more significant. Besides, the development of financial sector is the one-way Granger cause of financial service trade. The findings are consistent with the reality. It's also found that the strict financial control is the main reason that financial service trade can't get a great development in match with the financial development of Shanghai.

\section{References}

[1] S. L. Wang and Z. B. Hu, An Empirical Study on the Joint Development between Service Trade and Service Economy: 1985-2006. Journal of International Trade, vol. 4, pp. 53-60.

[2] Y. Z. Wang and J. Z. Wang, Interactive Relation between Services Trade and Development of the Service Industry in China-An Empirical Analysis Based on the 3D VAR model. Systems Engineering, vol. 30, pp. 16-21.

[3] C. H. Pei and Z. Y. Yang, The Analysis on Comparison Between Growth of Service Trade and Service Sector Since 2000. Finance \& Trade Economics, vol. 11, pp. 5-13.

[4] B. Q. Tang, J. J. Yang and Z. H, Chen, Research Overview on the Impact of Trade in Services to China's Economic Growth. Economic Perspectives, vol. 11, pp. 135-138.

[5] M. Z. Yu, The Empirical Analysis on the International Trade in Service Promoting Zhejiang's Economic Growth. Economic Issues, vol. 7, pp. 55-58.

[6] Z. Q. Wu, Z. Wang and C. J. Zhang, An Empirical Study on Relationship between China's International Service Trade and Economic Growth-Analysis Based on VAR Model. Macroeconomics, vol. 4, pp. 72-78.

[7] S. Y. Jiang, Empirical Analysis on the Influencing Mechanism of Service Trade and Economic Growth in China. Journal of International Trade, vol. 3, pp. 71-78.

[8] B. Q. Tang, F. H. Huang and J. J. Yang, Service Export, Intellectual Property Rights Protection and Economic Growth. China Economic Quarterly, vol. 11, pp. 155-180.

[9] J. Pan, International Trade in Service and China's Economic Growth: an Empirical Analysis and Some Suggestions. Contemporary Finance \& Economics, vol. 4, pp. 95-99.

[10] B. Cao and L. B. Liao, Service Trade Structure and Economic Growth. World Economy Study, vol. 1, pp. 46-51.

[11] X. Dai, Technological Level of Export in Service and Economic Development. Nankai Economic Studies, vol. 3, pp. 57-68.

[12] X. Yao and G. Li, Research on Relationship between Service Trade Liberalization and Economic Growth: Base on Empirical Analysis of Absorptive Capacity Perspective, vol. 7, pp. 68-74.

[13] B. Q. Li, A Study on the Mechanism of Coupling Coordinated Development Between Service Trade and Service Industry in China. Journal of Guizhou Normal University(Social Science), vol. 164, pp. 88-94.

[14] J. Y. Cao, Another Discussion on the Relations of Trade in Service and Economic Growth in China. Journal of Foreign Economic and Trade University, vol. 4, pp. 62-66.

[15] Q. Q. Xiong and Y. G. Zhang, The Contribution of Service Trade to Economic Growth: An Empirical Study based on China's Data from 1982 to 2006. World Economy Study, vol. 177, pp. 3-7. 